\title{
ACCULTURATIVE ICONIC PRODUCT ATTRACTIVENESS AND MARKETING PERFORMANCE
}

\author{
*Augusty Tae Ferdinand \\ ** Lili Karmela Fitriani \\ *Diponegoro University, Indonesia \\ ${ }^{* * *}$ Kuningan University, Indonesia
}

\begin{abstract}
This study was conducted to fulfill a research gap in the ability of product innovation to enhance marketing performance. This study proposed the concept of acculturative iconic product attractiveness for bridging the gap between product line innovation capability in increasing marketing performance. Sample data from 298 Batik SME in Cirebon District in Indonesia was used to test our model comprising four hypotheses. Our statistical test confirmed our model with four variables: product line innovation capability, acculturative iconic product attractiveness, consumer's need adaptability and performance, indicated that acculturative iconic product attractiveness holds a strategic role in enhancing marketing performance.
\end{abstract}

Keyword: Product Line Innovation Capability; Consumer's Need Adaptability; Acculturative Iconic Product Attractiveness; Product Competitive Advantage.

\section{INTRODUCTION}

To cope with the complexity of market environment, especially for they who work with a less- sophisticated technology in designing and producing product as witnessed in SME in Indonesia, innovation is something critical and a must for providing competitive product into the market through new product variety and seen a an engine for growth (Torun \& Çicekci, 2007). Companies to win a competition always try to offer very innovative products as a line of strategy for increasing the attractiveness of products to be offered in the market, strengthen the product's uniqueness or innovativeness. As proved in the study of (Shan, Song, \& Ju, 2015) innovativeness and innovation speed are recognized as strategic drivers for performance.

Our literature provides evidence on the influence of innovation on performance such as appeared in several studies (Molina-Castillo, Jimenez-Jimenez, \& Munuera-Aleman, (2011); Rhee, Park, \& Lee, (2010); Shan et al., 2015). Those studies demonstrated innovation has a positive impact on marketing performance. Study of Cheng, Chang, and Li (2013) demonstrated that no single path for success of product innovation and among others, the newness of innovation is a source of the marketing success. Even though product advantage is considered important to foster marketing performance, the study of García, Sanzo, and Trespalacios (2008) concluded that product advantage has no significant influence on marketing performance; this is to say that it is necessary to get another kind of support for product advantage to get rid on enhancing the marketing performance. Study on innovation provides a gap in the inability of product line innovation in influencing company performance as among others appeared in the study of Cillo, De Luca, and Troilo (2010) demonstrated that innovation has no significant impact on company performance. More over a study conducted by Liao and Cheng (2014) shows the impact of failures of innovation such as damage to brand reputation after a failure of innovation of the high-equity brand. Another study conducted by Santos, Basso, Kimura, and Kayo (2014) indicated little evidence that innovation in one period has a positive impact on the performance of a firm in the next period. These mixed result of the impact of innovation on performance provided research gap on the inability of product innovation in enhancing product advantage and marketing performance. Therefore, further research is still necessary.

To cope with this research gap, the objective of this study is to develop a conceptual model comprising a strategic bridge between innovation, product advantage and company performance regarding marketing performance. To develop our conceptual model, we proposed a concept of acculturative iconic product attractiveness as a strategic bridge for an innovation effort for maintaining and increasing marketing performance. 
To test our model empirically, we choose Batik Industry firm in Indonesia, especially in Cirebon Region of West Java Province. Batik was one of the Indonesian cultural heritages as decided by UNESCO in 2009. As an Indonesia icon, Batik should be managed and maintained as cultural heritage and simultaneously as a potential business driver in Indonesia as Batik Industry is well-known for its uniqueness. Batik, which is characterized by its uniqueness in style and motif, is embedded in Indonesian daily life in almost all part of Indonesia(Bakhtiar, Susanty, Sriyanto, \& Handayani, 2010; Iriani \& Priyanto, 2013; Setyanti, Troena, Nimran, \& Rahayu, 2013; Shaari, 2015; Treda, 2008), is seen as a kind of Indonesia uniqueness. This uniqueness is the reason we consider Batik Industry as our research object for empirically testing our model on innovation.

Tight competition in the country with very demanding consumers in choosing a product drives Batik Industry firms to be always more innovative in offering better product compared to competitors in the marketplace. Meanwhile study of Anwar, Rahab, and Priyono (2015) described Indonesian Batik SMEs are lacking good management practices, lacking of core values, technical innovation that may bring the industry to a slowdown growth. Penetration of printed Batik from Japan and Korea is a real threat in the industry for SME with traditional management (Setyanti, Eka Afnan Troena, Nimran, \& Rahayu, 2013). Creativity in product design and accuracy in market targeting and market entry was identified as key factors for competing with the foreign printed batik entering the Indonesian market. To cope with the competing market, domestic Batik Industry firm should emphasize on several critical factors such as offering's competitiveness, innovative design, creativity to access the market, innovative marketing strategy if they are going to maintain their product market from the infiltration of domestic competitors as well as foreign brand competitors.

Our study is aimed at developing and testing a conceptual model on how to manage product innovation by inserting a strategic mediating factor, named as acculturative iconic product attractiveness as drivers for increasing marketing performance. We used consumer's need adaptability to strengthen the acculturative iconic product attractiveness as well as markeiting performance.

\section{LITERATURE REVIEW AND MODEL DEVELOPMENT}

\section{Acculturative Iconic Product Attractiveness}

Study on product and its related attributes for attracting consumers is one of the anchor studies in product strategy. Classical point of view in marketing strategy for decades explained the importance of product design as a key driver for the success of the product in getting into the marketplace such as still appear in the current marketing literature. Good design for a product is not important only for the appearance of the product but also for attracting the potential consumer to look at and try to use the product. Product design process is started from understanding consumer needs and to some extent involves the consumer in designing process. As studied by Shri. Suresh Tulshiram Salunke and Srivastava (2013) core product is a basis for creating marketing performance, product design process is seen as an attempt to provide something more attractive to the marketplace for enhancing the attractiveness of core product, by adding certain icons such as name, face, picture, symbols leading to certain attractiveness (Hisarciklilar \& Boujut, 2009)

The icon that was widely studied in computer science (Rao, Zelinsky, Hayhoe, \& Ballard, 2002; Sung \& Hu, 2006) is important in product strategy research as the icon is used to associate features with certain objects (Rao \& Ballard, 1995). In the product design process, the company is trying to create whatever attractive to its product, resulted in a kind of iconic attributes that hold potentials for attracting the potential consumer to look at and buy a product.

In a country with a multiethnic background, a multi-culture background such as in Indonesia, icon could be developed with a multi-ethnic features coming out from the interaction of those multi-ethnic and multicultural society members. By interacting with those multi-ethnic and multi-culture society, a company has a chance to select and chose certain elements of foreign culture and domestic culture (Celenk, 2011), and to combine those attributes to be a specific to be attached to product they develop, resulting a product with several attribute attractiveness as conceptualized in our study as acculturative iconic product attractiveness. 


\section{Product Line Innovativeness}

Product innovativeness has been widely studied in the marketing field. Product innovativeness is considered as a key driver for success in the marketplace through a series of key initiatives. That initiatives are ability and success to be the first to market new product and new service, ability and success to be perceived as very novel by customers, ability and success in introducing more innovative product and services, ability and success to be faster in bringing new product and services into the market (Akgün, Keskin, \& Byrne, 2014; Avlonitis \& Salavou, 2007; Banerjee, 2003; Bayhan, Serinkan, \& Arat, 2013; Bicen, Kamarudin, \& Johnson, 2014; Boso, Story, \& Cadogan, 2013; Molina-Castillo et al., 2011; Rhee et al., 2010; Teece, 2010). Innovativeness is related to develop something novel, attractive, first to the market and hold a potential to attract consumers in the marketplace.

As discussed in the previous part of this research, in order to enhance the attractiveness of products to be offered in the marketplace, an innovative product will be developed with a combination of elements from several cultures that are melted together in a product is known as acculturative product as appeared in the study of Sulistiyani (2012) based on an acculturative innovation product. Innovative product design and unique product attributes are often seen a differentiator between products offered in the marketplace. A product with several iconic attributes with a melted multi-cultural elements is seen a kind of quality covered in a product thus holds a potential to attract the consumer. Therefore, the following hypothesis is proposed.

H1: The higher the product-line innovativeness, the more the attractiveness of iconic acculturative product

\section{Consumer Need Adaptability}

Study on market sensing has been done for decades (Day, 1994; Foley \& Fahy, 2009; Hughes, Morgan, \& Kouropalatis, 2008; Lindblom, Olkkonen, Mitronen, \& Kajalo, 2008; Lings \& Greenley, 2010) demonstrated the importance of understanding the market signals, especially consumer's needs appeared in the market place for further strategy anticipation and development. Study of Lindblom et al. (2008) pinpointed that company should manage the market sensing process through market sensing activities, sense-making activities and response to the market by utilizing the gathered and interpreted information for better strategy implementation.

To understand how company adapt to changing in consumer need, several study demonstrated how consumer is interesting in product attributes that mirroring certain values, such as response on the packaging with religious cues-symbols, names, color, style (Bakar, Lee, \& Rungie, 2013), with acculturative values (Sulistiyani, 2012). A company should develop a kind of ability in adapting product such as adding some new attributes that providing values for the consumer (Fiore, Kim, \& Lee, 2005) which hold potential in enhaning the product attractiveness and in turn enhancing the the marketing peroformance. Therefore, the following hypothesis is proposed.

H2: The higher the degree of consumer's need adaptability, the more the attractiveness of the iconic acculturative product.

\section{Marketing Performance}

Marketing performance concept is widely discussed in so many scholarly researchers demonstrating various measures used to indicate company performance in marketing field or division. Marketing performance could be understood as a construct with several indicators such as sales growth, market share, and sales to existing customer (Chang, Park, \& Chaiy, 2010), market share and growth of sales (García-Villaverde, Ruiz-Ortega, \& Ignacio Canales, 2013), acquiring new customers and increasing sales to existing customers(Krush, Agnihotri, Trainor, \& Nowlin, 2013),stronger growth in sales revenue, better able to acquire new customers, greater market share and sales increase to existing customers(Merrilees, Rundle-Thiele, \& Lye, 2011), market share of brand, sales growth of brand(O'Cass \& Weerawardena, 2010) and market share (Wu, 2013).

If a product or a portfolio of products gain its attractiveness through variety of acculturative iconic product attractiveness, then as already studied by several scholars such as Sulistiyani (2012), Wingwon (2012) and (Chang, Tein, \& Lee, 2010), it has a possibility to enhancing marketing performance. Therefore, the following hypotheses are proposed.

H3: The more the attractiveness of iconic acculturative product, the higher the marketing performance 
H4: The higher the degree of consumer's need adaptability, the higher the marketing performance.

Based on our literature review and those hypotheses developed in this study, an empirical research model is proposed as in the following figure.

Figure 1 Empirical Research Model

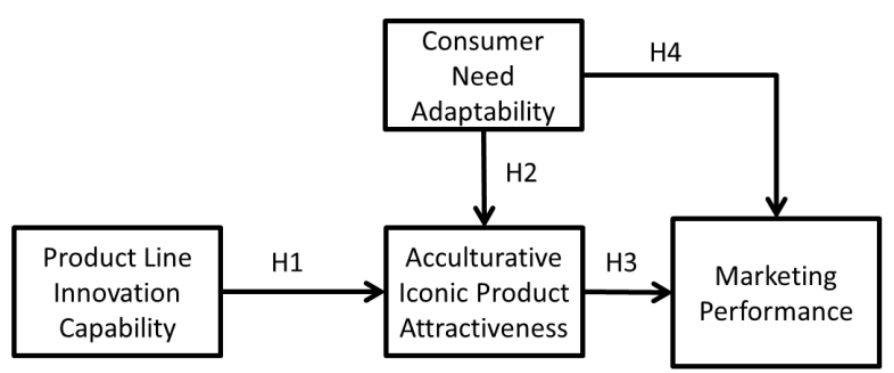

\section{RESEARCH METHOD}

Data was collected from a sample data from 310 SMEs in Cirebon District for testing the model and hypotheses. Sampling technique was a purposive sampling by setting several criteria such as minimum year of business is three year indicating the experience in competing in the marketplace and with a series or product that regional icon-based design. After treatment of normality, remain 298 respondents are used for further statistical analysis. To operationalize our variables used the model, the meaning, and its related indicators are presented in the following table.

Table 1 Variable and Indicator

\begin{tabular}{|l|l|ll|}
\hline \multicolumn{1}{|c|}{ Variable } & \multicolumn{1}{|c|}{ Core Meaning } & \multicolumn{1}{c|}{ Indicators } \\
\hline $\begin{array}{l}\text { Product line } \\
\text { innovation } \\
\text { capability }\end{array}$ & Capability in innovating product line & $\begin{array}{l}\text { 1. } \\
2 .\end{array}$ & $\begin{array}{l}\text { Product Variety Making Capability } \\
\text { Specific Design Capability } \\
\text { Differentiated Branding Capability }\end{array}$ \\
\hline $\begin{array}{l}\text { Consumer Need } \\
\text { Adaptability }\end{array}$ & $\begin{array}{l}\text { Ability to adapt the consume need when } \\
\text { market change happen }\end{array}$ & $\begin{array}{l}\text { Adaptability to market change } \\
\text { 2. }\end{array}$ & Adaptability to product motif in a risky market \\
\hline $\begin{array}{l}\text { Acculturative } \\
\text { iconic product } \\
\text { attractiveness }\end{array}$ & $\begin{array}{l}\text { The degree of activeness of a product } \\
\text { attributes as seen as an icon that is } \\
\text { combining several cultural element from }\end{array}$ & $\begin{array}{l}\text { 3. Acculturative Motive Attractiveness } \\
\text { two or more cultures. }\end{array}$ & $\begin{array}{l}\text { Acculturative Style Attractiveness } \\
\text { Acculturative Symbol Attractiveness }\end{array}$ \\
\hline $\begin{array}{l}\text { Marketing } \\
\text { performance }\end{array}$ & $\begin{array}{l}\text { The degree of marketing achievement in } \\
\text { the marketplace }\end{array}$ & $\begin{array}{l}\text { 1. } \\
2 .\end{array}$ & $\begin{array}{l}\text { Sales Volume } \\
\text { Sales Value } \\
\text { Sales Growth in new area }\end{array}$ \\
\hline
\end{tabular}

Data Analysis

Data analysis process is done by checking the fulfilling of multivariate statistics assumption of data profile, to ensure that data is normally distributed. Data from four variables indicated a non-normal distribution pattern. Therefore, we deploy the procedure of Tabachnick and Fidell (2012). Four variables have severe positive skewness. Therefore, data were transformed with $1 / \mathrm{X}$ technique. After data normalizing process, the analysis was re-run; a normally distributed data pattern is achieved. Data was then analyzed using AMOS 21 statistic software for a full structural equation model.

Our structural model analysis demonstrated good model acceptance level as concluded from several indices such as $\chi^{2}=44.417$; Significance Probability $=0,254 ; \mathrm{CMIN} / \mathrm{DF}=1,139 ; \mathrm{GFI}=0.974 ;$ AGFI=0,957; TLI = 0,989; CFI $=0,992$; RMSEA $=0,022$, therefore our model fit with the expected population. The structural model is presented in the following Figure 2. 
Figure 2 Model Testing

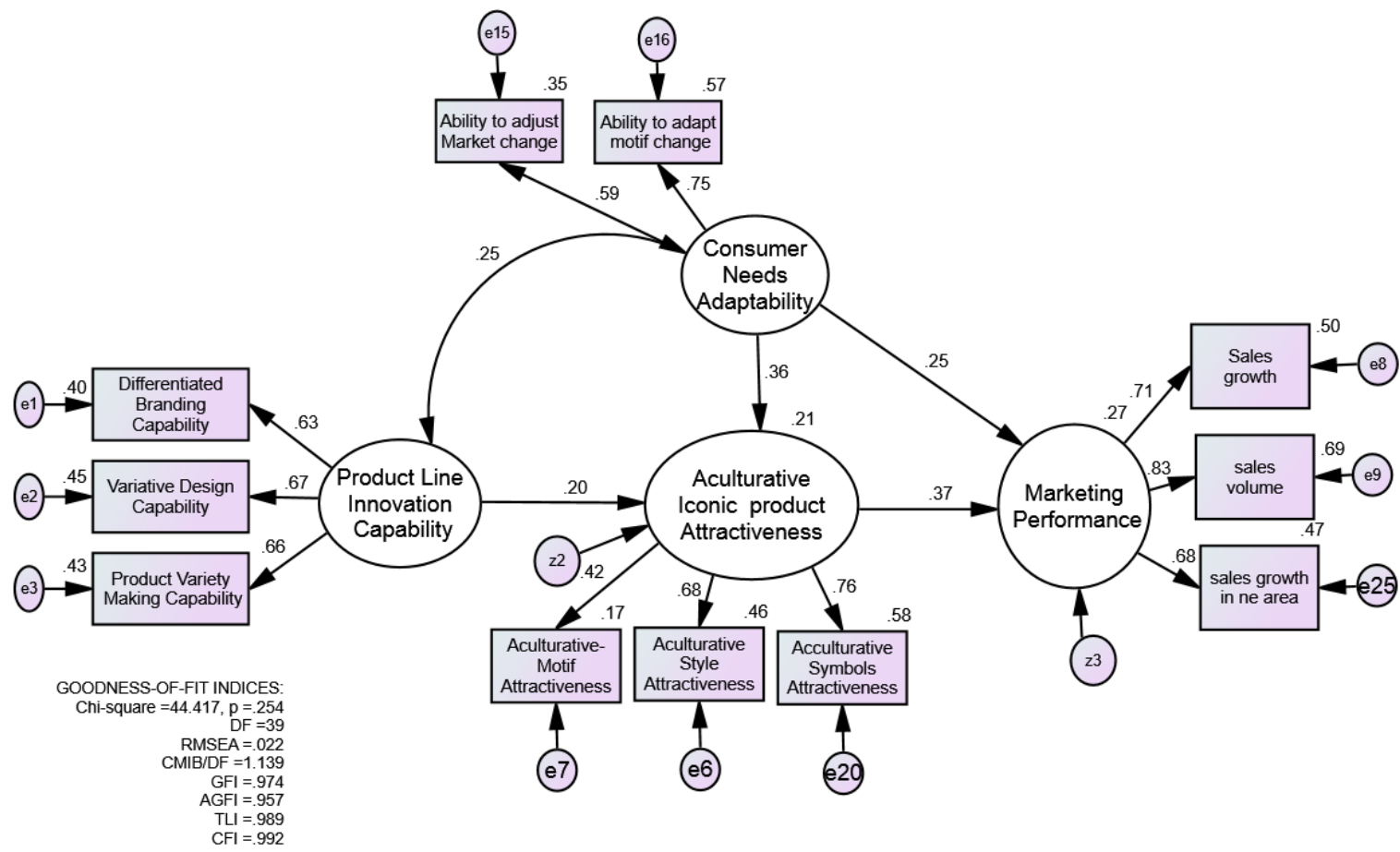

The structural coefficient for regression analysis is presented in the following Table 2 .

Table 2 Hypothesis testing

Hypothesis

Standardized Estimate

\begin{tabular}{|c|c|c|c|c|}
\hline $\begin{array}{l}\text { Product line innovation } \\
\text { capability }\end{array}$ & $\rightarrow$ & $\begin{array}{l}\text { Acculturative iconic product } \\
\text { attractiveness }\end{array}$ & .203 & 0.023 \\
\hline $\begin{array}{l}\text { Acculturative Iconic } \\
\text { Product Attractiveness }\end{array}$ & $\rightarrow$ & Marketing performance & .373 & $* * *$ \\
\hline $\begin{array}{l}\text { Consumer's need } \\
\text { adaptability }\end{array}$ & $\rightarrow$ & $\begin{array}{l}\text { Acculturative iconic product } \\
\text { attractiveness }\end{array}$ & .364 & $* * *$ \\
\hline $\begin{array}{l}\text { Consumer's need } \\
\text { adaptability }\end{array}$ & $\rightarrow$ & Marketing Performance & .245 & 0.010 \\
\hline
\end{tabular}

As presented in Table 2, all hypotheses were tested; the significance probability is lower than $5 \%$ for every relationship between hypothesized variables, we can draw a conclusion that all hypotheses are supported by data of our sample.

\section{CONCLUSION}

As stated at the beginning of this study that the objective of the present study is to fulfill a research gap on the inability of product line innovation capability in enhancing marketing performance. The acceptance of our hypothesized model and relationships demonstrates several ways to enhance marketing performance. The first pathway is a company with high adaptability to consumer's need will increase the attractiveness of acculturative iconic product leading to marketing performance. This type of consumer's need adaptability such as the ability to adapt to market change and adaptability to motif change in product design is expected to be a driver for increasing the attractiveness of acculturative iconic product attributes as leverage for enhancing marketing performance. The second pathway is a a company with product line innovation capability is expected to strengthen the attractiveness of acculturative iconic product as a driver for 
enhancing marketing performance. The third pathway is that if a company regularly adapt to consumer's need, this marketing behavior is a triger for enhancing the marketing performance.

This study explains that product line innovation capability, managed by company to empower the attractiveness of a product offered on the market by smartly combine attributes rooted in the culturalhistorical values, hetero-cultural symbols and symbolic values, hetero cultural style, melted together in forming an acculturative iconic product attributes, leading to a level of inimitability of a product and enhancing marketing performance. This study demonstrated that even though product attractiveness is recognized as a strategic factor for enhancing marketing performance, the attractiveness of a product should be continuously maintained by inserting several acculturative attributes. As studied by Singh (2013), those efforts for enhancing the quality of product appearance is potential for success in competing in the marketplace.

The present study come out to a conclusion that if company can manage its capability to innovate product line, considering several social, cultural factors in product design process, then company will inserting elements of socio-cultural factor melting together in the appearance of a product, leading to a kind of acculturative iconic attribute that having potential to enhance product (Hoonsopon, 2009) and competitive advantage (Tung, 2012). Batik SMEs in Cirebon district of produce batik with a variety of iconic acculturative attributes with iconic acculturative uniqueness is seen as a driver for enhancing performance.

\section{Limitation and further research}

As happened in other research, our research has several limitations. Firstly, the ability of product line's innovation capability and consumer's need adaptaibilty variables in explaining the variation of acculturative iconic product attractiveness is low, only $21 \%$ indicating that is necessary to find and to add other key variables for enhancing the attractiveness of the acculturative iconic product. Secondly, the ability of adaptability to consumer's need and acculturative iconic product attractiveness to explain the variation of marketing performance is $28 \%$ indicating a necessary to add a more strategic variable for enhancing the performance. Therefore, several research venues are open for seeking strategic variable that potential to enhance marketing performance. 
Journal of Global Strategic Management | V. 9 | N. 2 | 2015-December | isma.info | 15-23 | DOI: 10.20460/JGSM.2015915570 REFERENCE

Akgün, A. E., Keskin, H., \& Byrne, J. C. (2014),Complex Adaptive Systems Theory and Firm Product Innovativeness. Journal of Engineering and Technology Management, 31: 21-42.

Anwar, N., Rahab, \& Priyono, R. E.(2015), Core Competence of Batik Banyumas Industry: Problems and Challenge to Createsustainable Competitive Advantage. I J A B E R, 13(1): 12.

Avlonitis, G. J., \& Salavou, H. E. (2007). Entrepreneurial Orientation of SMEs, Product Innovativeness and Performance. Journal of Business Research, 60(5): 566-575.

Bakar, A., Lee, R., \& Rungie, C.(2013), The Effects of Religious Symbols in Product Packaging on Muslim Consumer Responses. Australasian Marketing Journal (AMJ), 21(3): 198-204.

Bakhtiar, A., Susanty, A., Sriyanto, \& Handayani, O. P. (2010),. Conceptual Model to Enhance Creativity of the Batik Industry, ICIEBM: 6. Yogyakarta.

Banerjee, P. (2003), Resources, Capability and Coordination: Strategic Management of Information in Indian Information Sector Firms. International Journal of Information Management, 23(4): 303-311.

Bayhan, M., Serinkan, C., \& Arat, G. (2013), Evaluation of Staff Attitudes Related to Innovation Management: An Empirical Study in a Service Sector in Turkey. Procedia - Social and Behavioral Sciences, 89: 323-327.

Bicen, P., Kamarudin, S., \& Johnson, W. H. A.(2014), Validating New Product Creativity in the Eastern Context of Malaysia. Journal of Business Research, 67(1): 2877-2883.

Boso, N., Story, V. M., \& Cadogan, J. W. (2013), Entrepreneurial Orientation, Market Orientation, Network Ties, and Performance: Study of Entrepreneurial Firms in a Developing Economy. Journal of Business Venturing, 28(6): 708-727.

Chang, S.-C. C., Tein, S.-W., \& Lee, H.-M. (2010), Social Capital, Creativity, and New Product Advantage: An Empirical Study. International Journal of Electronic Business Management 8(1): 43-55.

Chang, W., Park, J. E., \& Chaiy, S. (2010), How does CRM Technology Transform into Organizational Performance? A Mediating Role of Marketing Capability. Journal of Business Research, 63(8): 849-855.

Cheng, C.-F., Chang, M.-L., \& Li, C.-S. (2013). Configural Paths to Successful Product Innovation. Journal of Business Research, 66(12): 2561-2573.

Cillo, P., De Luca, L. M., \& Troilo, G. (2010), Market Information Approaches, Product Innovativeness, and Firm Performance: An Empirical Study in the Fashion Industry. Research Policy, 39(9): 1242-1252.

Day, G. S. (1994), The Capabilities of Market-Driven Organization. Jourbal Of Marketing, 58(4): 16.

Fiore, A. M., Kim, J., \& Lee, H.-H.(2005), Effect of Image Interactivity Technology on Consumer Responses Toward the Online retailer. Journal of Interactive Marketing, 19(3): 38-53.

Foley, A., \& Fahy, J. 2009. Seeing Market Orientation Through a Capabilities Lens. European Journal of Marketing, 43(1/2): 13-20.

García-Villaverde, P. M., Ruiz-Ortega, M. J., \& Ignacio Canales, J. (2013), Entrepreneurial Orientation and the Threat of Imitation: The Influence of Upstream and Downstream Capabilities. European Management Journal, 31(3): 263-277.

García, N., Sanzo, M. J., \& Trespalacios, J. A.(2008), New Product Internal Performance and Market Performance: Evidence from Spanish Firms Regarding The Role of Trust, Interfunctional Integration, and Innovation type. Technovation, 28(11): 713-725.

Hisarciklilar, O., \& Boujut, J.-F. (2009), A Speech Act Theory-based Information Model to Support Design Communication Through Annotations. Computers in Industry, 60(7): 510-519.

Hughes, P., Morgan, R. E., \& Kouropalatis, Y.(2008), Market Knowledge Diffusion and Business Performance. European Journal of Marketing, 42(11/12): 1372-1395. 
Journal of Global Strategic Management | V. 9 | N. 2 | 2015-December | isma.info | 15-23 | DOI: 10.20460/JGSM.2015915570

Iriani, A., \& Priyanto, S. H. (2013), Modeling of Employee Relationships in SME Batik: Case Study of Windasari Batik. Asian Journal of Management Sciences \& Education, 2(4): 14.

Krush, M. T., Agnihotri, R., Trainor, K. J., \& Nowlin, E. L. (2013), Enhancing organizational sensemaking: An examination of the interactive effects of sales capabilities and marketing dashboards. Industrial Marketing Management, 42(5): 824-835.

Liao, S., \& Cheng, C. C. J. (2014), Brand Equity and The Exacerbating Factors of Product Innovation Failure Evaluations: A Communication Effect Perspective. Journal of Business Research, 67(1): 2919-2925.

Lindblom, A. T., Olkkonen, R. M., Mitronen, L., \& Kajalo, S. 2008. Market-Sensing Capability and Business Performance of Retail Entrepreneurs. Contemporary Management Research, 4(3): 17.

Lings, I. N., \& Greenley, G. E. (2010). Internal Market Orientation and Market-oriented Behaviours. Journal of Service Management, 21(3): 321-343.

Merrilees, B., Rundle-Thiele, S., \& Lye, A. 2011. Marketing Capabilities: Antecedents and Implications for B2B SME Performance. Industrial Marketing Management, 40(3): 368-375.

Molina-Castillo, F.-J., Jimenez-Jimenez, D., \& Munuera-Aleman, J.-L. (2011). Product Competence Exploitation and Exploration Strategies: The Impact on New Product Performance Through Quality and Innovativeness. Industrial Marketing Management, 40(7): 1172-1182.

O'Cass, A., \& Weerawardena, J. (2010). The Effects of Perceived Industry Competitive Intensity and Marketing-Related Capabilities: Drivers of Superior Brand Performance. Industrial Marketing Management, 39(4): 571-581.

Rao, R. P. N., \& Ballard, D. H. (1995), An Active Vision Architecture Representations Based on Iconic Representations. Artificial Intelligence, 78: 45.

Rao, R. P. N., Zelinsky, G. J., Hayhoe, M. M., \& Ballard, D. H. (2002), Eye Movements in Iconic Visual Search. Vision Research, 42: 17.

Rhee, J., Park, T., \& Lee, D. H.(2010). Drivers of Innovativeness and Performance for Innovative SMEs in South Korea: Mediation of Learning Orientation. Technovation, 30(1): 65-75.

Santos, D. F. L., Basso, L. F. C., Kimura, H., \& Kayo, E. K. (2014),Innovation Efforts and Performances of Brazilian Firms. Journal of Business Research, 67(4): 527-535.

Setyanti, S. W. L. H., Eka Afnan Troena, Nimran, U., \& Rahayu, M. (2013), Innovation Role in Mediating the Effect of Entrepreneurship Orientation, Management Capabilities and Knowledge Sharing Toward Business Performance: Study at Batik SMEs in East Java Indonesia. IOSR Journal of Business and Management, Volume 8, (Issue 4): PP 16-27.

Setyanti, S. W. L. H., Troena, E. A., Nimran, U., \& Rahayu, M.(2013). Innovation Role in Mediating the Effect of Entrepreneurship Orientation, Management Capabilities and Knowledge Sharing Toward Business Performance: Study at Batik SMEs in East Java Indonesia. Journal of Business and Management, 8(4): 12.

Shaari, N.( 2015). Indigenous Knowledge Creativity in Batik Cultural Product based on Kansei, International Conference on Social Sciences and Humanities (ICSSH'15) May 5-6, 2015 Bali (Indones. Bali, Indonesia: ICSSH.

Shan, P., Song, M., \& Ju, X. 2015. Entrepreneurial orientation and performance: Is Innovation Speed a Missing Link? Journal of Business Research.

Shri. Suresh Tulshiram Salunke, \& Srivastava, R. K. (2013), The impact of Core Product and Core Application on Product Launch and its Success in an Industrial Market. Basic Research Journal of Education Research and Review, Vol. 2(1) 16-21.

Singh, M. (2013). Product Quality for Competitive Advantage In Marketing. International Journal of Business and Management Invention, 2(6): 05-08.

Sulistiyani. (2012). Membangun Kinerja Pemasaran Melalui Pembelajaran Generatif Berbasis Budaya dan Inovasi Akulturasi. Diponegoro University, Indonesia. 
Journal of Global Strategic Management | V. 9 | N. 2 | 2015-December | isma.info | 15-23 | DOI: 10.20460/JGSM.2015915570

Sung, S. Y., \& Hu, T.(2006). Iconic Pictorial Retrieval Using Multiple Attributes and Spatial Relationships. Knowledge-Based Systems, 19(8): 687-695.

Tabachnick, B. G., \& Fidell, L. S.(2012). Using Multivariate Statistics (6 ed.). New York: Pearson Publisher.

Teece, D. J. 2010. Business Models, Business Strategy and Innovation. Long Range Planning, 43(2-3): 172194.

Torun, H., \& Çicekci, C. (2007). Innovation: is The Engine for The Economic Trowth? Research Paper.

Treda.( 2008). Indoneisan Batik: a Cultural Beauty. In T.-T. R. a. D. Agendy (Ed.). Jakarta.

Wingwon, B.(2012). Effects of Entrepreneurship, Organization Capability, Strategic Decision Making and Innovation Toward the Competitive Advantage of SMEs Enterprises. Journal of Management and Sustainability, Vol. 2, No. 1;.

Wu, J. (2013). Marketing Capabilities, Institutional Development, and the Performance of Emerging Market Firms: A Multinational Study. International Journal of Research in Marketing, 30(1): 36-45. 